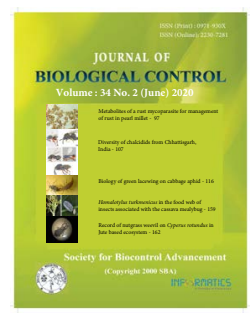

Research Article

\title{
Metabolites of the rust mycoparasite, Sphaerellopsis paraphysata for management of rust in pearl millet
}

\author{
P. ASHMITHA SRI, V. SENDHILVEL and T. RAGUCHANDER* \\ Department of Plant Pathology, Centre for Plant Protection Studies, Tamil Nadu Agricultural University, Coimbatore - 641003, Tamil Nadu, \\ India \\ *Corresponding author E-mail: raguchander@rediffmail.com
}

\begin{abstract}
The mycoparasite, Sphaerellopsis paraphysata was isolated from the uredospores of pearl millet rust pathogen Puccinia substriata with promising natural parasitic association. The culture had definite margin, sometimes submerged in media and sporulation occurred on the third week of incubation. The mycelium was hyaline and septate. The secondary metabolites were explored to contain the uredospore production thereby reduce the rust incidence. The solvent extraction method was used to extract the secondary metabolites produced from crude extracts of $S$. paraphysata. The fractions of the secondary metabolites were analyzed using GC-MS. The major components present were Phenol, Decane, 3-Butoxy-1,1,1,5,5,5, hexamethyl-3-(trimethylsiloxy) trisiloxane, Butanoic acid, 3-methyl-3-methyl butyl ester, which were reported to have anti-microbial, anti-fungal and anti-oxidant properties. The crude metabolite of $S$. paraphysata in the dilution of 1:5 recorded the maximum lysis of the uredospores of $P$. substriata $(92.67 \%)$. Further, SEM study showed severely lysed broken cell wall which led to leakage of cellular contents. The spraying of secondary metabolites on rust infected pearl millet crop reduced the incidence of rust. The present study paved the way for the development of new biologically originated molecule for the management of pearl millet rust disease.
\end{abstract}

KEY WORDS: Pearl millet, rust, secondary metabolites, Sphaerellopsis paraphysata

(Article chronicle: Received: 12-02-2020; Revised: 20-05-2020; Accepted: 22-05-2020)

\section{INTRODUCTION}

The pearl millet crop is affected by several biotic and abiotic factors that cause significant reduction in the yield of the crop. The pearl millet leaf rust caused by Puccinia substriata is the most destructive and results in yield loss upto 76\% (Wilson et al., 1996). The uredial, telial and basidial stages of the macrocyclic rust pathogen are found on pearl millet. The spermagonial and aecial stages occur in alternate host viz. Solanum melongena (eggplant) (de Carvalho et al., 2006). Since the fungicidal control of rust disease has hazardous impact on environment, there exists a huge need for alternatives like natural biological originated antagonistic organisms. The new isocyanide antimicrobial metabolites such as darlucin A (1) and B (2), were isolated from Sphaerellopsis filum by fermentation process, which exhibited antibacterial and antifungal activity (Zapf et al.,1995). Hence, the present study was focused on the isolation, separation and assay of the secondary metabolites of mycoparasite, Sphaerellopsis paraphysata to contain the rust uredospore production.

\section{MATERIALS AND METHODS}

\section{Collection and isolation of mycoparasitic fungi}

Mycoparasitic fungus viz., Sphaerellopsis paraphysata was isolated from pearl millet rust samples collected from different location of Tamil Nadu. The single pycnidial method explained by Driessen et al. (2004) was used in this study for the isolation of S. paraphysata. In this method, the pycnidia of $S$. paraphysata in the rust infected leaves were scraped and pycnidia were dipped in sodium hypochlorite for $30 \mathrm{sec}$ and then mixed with water agar medium, after the solidification of the media the pycnidia dispersed randomly in the water agar were marked with a marker under stereozoom microscope and incubated at $25^{\circ} \mathrm{C}$ for 48 hours and then the germinated spores were located and marked which are transferred to another petridish containing V8 juice agar. Streptomycin was added to prevent the bacterial contamination. Inoculated petriplates were incubated for $20^{\circ} \mathrm{C}$ for 25 days. Pure culture of the biocontrol agent was obtained by single hyphal tip method (Leyronas et al., 2012). The stock cultures were sub cultured at an interval of 30 days to maintain the viability of 
the culture and further studies.

\section{Extraction of Sphaerellopsis paraphysata crude metabolites in vitro}

Potato Dextrose Agar (PDA) broth was prepared and uniformly transferred to $250 \mathrm{ml}$ Erelynmeyer flasks as each containing $100 \mathrm{ml}$ and sterilized in an autoclave at $15 \mathrm{lbs}$ pressure for $20 \mathrm{~min}$ and cooled. The potential isolate TNAU-Sp3 was inoculated in each flask and incubated at $25^{\circ} \mathrm{C}$ for 20 days. The culture filtrate of the isolate was taken and centrifuged at 10000 rpm for 15 minutes and filtered with Whatman no 1 filter paper. Solvent extraction method was used to extract the secondary metabolites present in the culture filtrate. Equal volume of ethyl acetate was added to the culture filtrate and secondary metabolites were separated using a separating funnel. The ethyl acetate extract was washed three times with $10 \mathrm{ml}$ of $5 \%$ sodium bicarbonate separately and again washed three times with $10 \mathrm{ml}$ of $5 \%$ sodium carbonate and finally with $10 \mathrm{ml}$ of sterile water, until it became neutral. Finally sodium sulphate was added to remove the moisture each solvent was evaporated at $55^{\circ} \mathrm{C}$ on a rotary evaporator separately and the crude extract (oily residues) obtained from each isolate was dissolved individually in one $\mathrm{ml}$ of methanol and ethyl acetate and stored in Eppendorf vials in refrigerated condition at $4^{\circ} \mathrm{C}$ for further use (Almeida et al., 2010).

\section{Detection of secondary metabolites by GC-MS}

The crude secondary metabolites produced by TNAUSp3 was analyzed through Gas Chromatography - Mass Spectrometry (GC-MS) (Thermo scientific Trace GC Ultra DSQ II) equipped with column $(30 \mathrm{~mm} \times 0.25 \mathrm{~mm} \times 0.25$ $\mu \mathrm{m})$ under the following conditions: carrier gas as Helium with flow rate at $1 \mathrm{ml}$ per minute and $1 \mu \mathrm{l}$ sample injection with pre injection of solvent by AI/AS 3000 Method; split-less mode injection with $30 \mathrm{sec}$ of sampling time; the column temperature maintained initially at $50^{\circ} \mathrm{C}$ at the increasing rate of $10^{\circ} \mathrm{C} \mathrm{min}^{-}$ ${ }^{1}$ no hold was followed by increasing upto $200^{\circ} \mathrm{C}$ and kept at the same temperature for 2 minutes hold with surge pressure $3 \mathrm{kPa}$ and $220^{\circ} \mathrm{C}$ base temperature at right SSL method and $250^{\circ} \mathrm{C}$ base temperature at right ECD method with the Aux 1 MS transfer line at $250^{\circ} \mathrm{C}$; the electron impact energy was 70 $\mathrm{eV}$, Julet line temperature was set at $2,000^{\circ} \mathrm{C}$ and the source temperature was set at $200^{\circ} \mathrm{C}$. Electron Impact (EI) mass scan $(\mathrm{m} / \mathrm{z})$ was recorded in the 45-450 aMU range. The total chromatogram was obtained for each sample separately. The base peak of each spectrum was compared with the base peak of the chemical components in the NIST Ver.2005 MS data library through on-line and the compounds were identified.

\section{Assay of secondary metabolites of Sphaerellopsis paraphysata on uredospores germination}

The assay of secondary metabolites was carried out by the methodology explained by Chaudhary et al. (2015). The crude extract was diluted with sterile water in the five different concentrations viz., 50, 100, 250, 500 and 1000 ppm and tested its efficacy on uredospore under cavity slide method. The crude metabolites and their respective concentrations were prepared by mixing the requisite quantity of sterilized distilled water. Fresh uredospores collected from single pustule of pearl millet rust infection were dispensed uniformly in sterilized distilled water in culture tubes. Single drop of uredospores suspension was placed in the wells of series of cleaned cavity slides by using one $\mathrm{ml}$ pipettes. Treatment without crude metabolites served as control. Cavity slides containing spore suspension were incubated at $20 \pm 10^{\circ} \mathrm{C}$ temperature in a BOD incubator. Four replications of each treatment maintained and four hundred uredospores were counted. The observation was made 24,48 and $72 \mathrm{~h}$ of incubation using different microscopic fields for each slide. Per cent lysis of spore germination over control was calculated as per the formula described by Vincent (1947).

\section{Efficacy of crude extracts of Sphaerellopsis paraphysata} against pearl millet rust under glass house condition

The susceptible check of pearl millet plants cultivar $\mathrm{CO}$ 10 was raised in glass house. The pots consisted Farmyard manure, red earth and sand $(2: 1: 1)$ and each pot was sown with five seeds. When the seedlings attained six leaf stage the leaves were sprayed with freshly collected uredospores at the concentration of $10^{6}$ per $\mathrm{ml}$ as described by Kishore and Pande (2005). The plants were then covered by polythene bag for 24 hours to maintain high humidity for disease development. Seven to ten days after inoculation, the visible symptoms were noticed with small pustules of uredospores. Then the crude extract with different concentrations viz., 50, 100, 250, 500 and 1000 ppm were sprayed and control was also maintained by spraying with sterile distilled water. The incidence of rust on leaves was recorded and severity was calculated as described by Ravinder Reddy (1982).

\section{Environmental SEM analysis of Sphaerellopsis paraphysata}

To study the parasitization of $S$. paraphysata on rust uredospores was confirmed by environmental scanning electron microscopic (ESEM) image analysis. The typical rust specimens were selected and morphologically examined. The leaf specimen was cut into a size of $5 \times 5 \mathrm{~mm}$ and directly fixed in carbon stubs coated with gold in a high vacuum evaporator (Sputter coating) and ESEM analysis was carried out using an acceleration voltage of 8-10 kV. Image capture control was achieved using Auto-Montage v.5.0 (Synoptics) and the images were captured as a series of focal planes and montage to produce a composite focused image. 


\section{RESULTS AND DISCUSSION}

Sphaerellopsis paraphysata TNAU-SP3 isolate with GenBank accession MK863554 has shown faster growth when compared to other isolates. The growth of TNAU-Sp3 (20 days to attain maximum growth) was comparatively faster than that of TNAU-Sp2 (MK 918510) (35 days to attain maximum growth). In our study, we have confirmed that the mycoparasite $S$. paraphysata found in the pearl millet rust is a hyperparasitic fungi which parasitizes the rust fungi and thus reduces the incidence of rust. Kranz and Brandenburger (1981) reported that Sphaerellopsis filum (anamorph of Eudarluca caricis) is a known mycoparasite of at least 369 species and its mode of action to degrade uredial sori, which result in stopping the propagation of uredospores and so prevents new rust infections (Gordon and Pfender, 2012).

Yuan et al. (1998) reported that Sphaerellopsis filum decreases the rust spore germination up to $98 \%$ with wide host range and used for integrated disease management in pearl millet cultivation.

\section{Identification of compounds from secondary metabolites of Sphaerellopsis paraphysata}

The secondary metabolites obtained from crude extracts of TNAU Sp3 was extracted with methanol and subjected to GC-MS analysis for identifying the secondary metabolites. The compound identity was verified by AMDIS software programme and NIST library 2005.

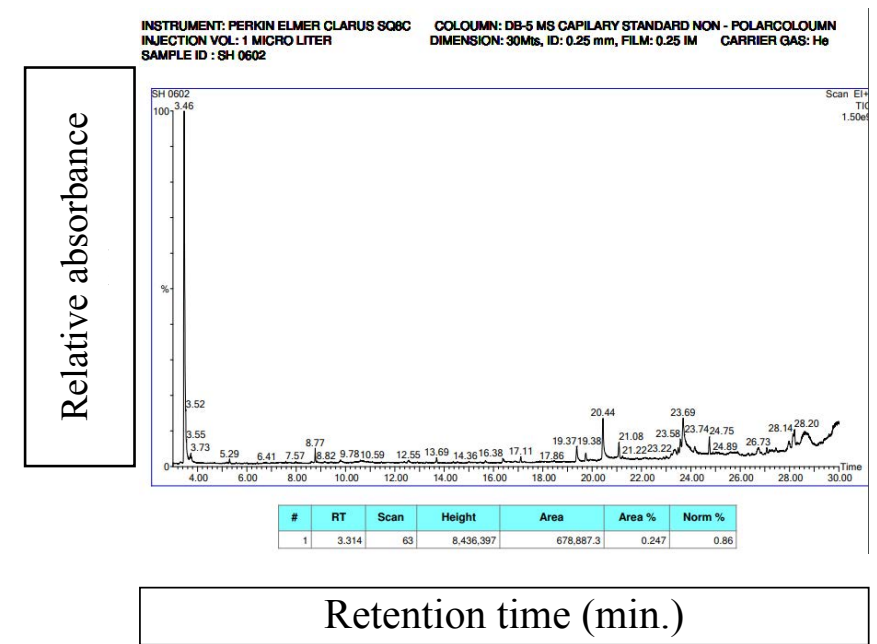

Plate 1. GC-MS chromatogram of secondary metabolites from crude extracts of Sphaerellopsis paraphysata

The crude extracts of TNAU Sp3 contained several secondary metabolites. The compounds with antimicrobial, antifungal and antioxidant properties were identified. They were Phenol, Decane, 3-Butoxy-1,1,1,5,5,5-hexamethyl3-(trimethylsiloxy) trisiloxane, Butanoic acid, 3- methyl,3methyl butyl ester, Pyridine,3-(1-methyl-2-pyrrolidinyl), 3-oxabicyclo[4.1.0] heptane-7-Carboxamide-6-methyl-N-(1napthyl), 1-Indolizin carboxylic acid, 2-methyl-,ethyl ester, N-N-Dimethyldecanamide (Plate 1) (Table 2). The antifungal compounds were identified in our studies were reported in several studies and showing antifungal, antibacterial and antioxidant properties (Jurd et al., 1971; Ansari et al., 2013; Venkatesan et al., 2017; Brahmi et al., 2016; Gupta et al., 2016; Ololade et al., 2017; Srivastava, 2014 and Muhialdin et al., 2016).

\section{Effect of different concentrations of crude metabolites on uredospore germination and rust incidence}

The crude metabolites extracted from $S$. paraphysata were tested with 50, 100, 250, 500 and $1000 \mathrm{ppm}$ concentration against uredospores of $P$. substriata. It is clearly noticed that in all the concentration the uredospores cell wall were lysed and broken, which resulted in the leakage of cellular contents. The maximum lysis of uredospores $(92.67 \%)$ was recorded in $1000 \mathrm{ppm}$ followed by $500 \mathrm{ppm}$ $(86.67 \%)$ at $72 \mathrm{~h}$ after incubation. The minimum spore lysis was recorded in sterile water $(2.33 \%)$ (Table 3; Plate 2). The lowest spore germination of $13.6 \%$ was recorded in $1000 \mathrm{ppm}$ concentration of crude metabolites. There is no reduction in germination of uredospore in sterile water treated control (Table 3). Rust infected pearl millet cultivar CO 10 was tested to prove the toxicity of crude extract of $S$. paraphysata against $P$. substriata. The results revealed that secondary metabolites at $1000 \mathrm{ppm}$ sprayed plants showed $92.6 \%$ reduction in rust symptom. Howeverm, the treatment sprayed with $50 \mathrm{ppm}$ showed lowest reduction $(56.3 \%)$ in rust symptom on foliage (Table 3 ). Uredospores treated with crude secondary metabolites at $1000 \mathrm{ppm}$ showed lysis of cell and leakage of cellular contents in SEM study. The uredospores were deformed as compared to healthy uredospores not treated with crude extracts of $S$. paraphysata (Plate3). The similar results were found in spore damage of Curvularia lunata when it was treated by metabolites obtained from Bryum cellulare (Deora and Guhil, 2015). Further, this study paves the possibility for exploring the naturally occurring antifungal phytochemicals for plant disease management. The results of the SEM observations from this study showed shrunken and lysed uredospores due to the treatment of secondary metabolites. Plachecka (2005) reported that hyphal penetration of $S$. filum into the uredospore and collapsed with disintegration. Similarly the mycoparasite, A. quisqualis was observed in SEM by Parthasarathy (2018) who stated that the parasitized conidia of Erysiphe pisi with Ampellomyces quisqualis was shrunken and deteriorated. Yuan et al. (1999) reported that $S$. filum reduced the spore production of Willow rust (Melamspora epitea) by $98.0 \%$.

The present investigation gives the scope for the exploration of secondary metabolites and bio chemical 


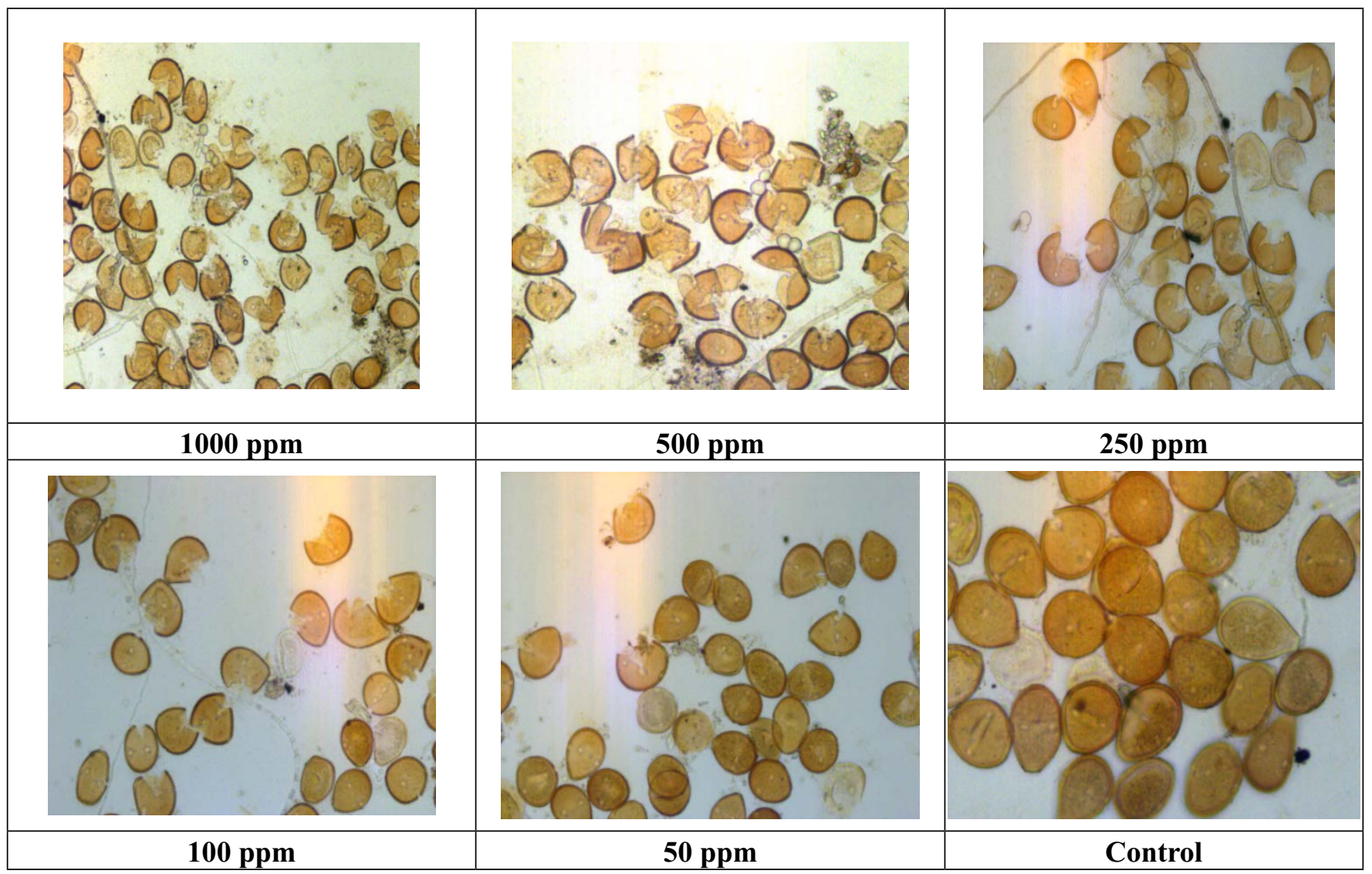

Plate 2. Bioassay of Sphaerellopsis paraphysata crude metabolites against uredospores of Puccinia substriata

\section{Dilution}

$1000 \mathrm{ppm}$ - Complete cleavage of spore wall

$500 \mathrm{ppm}-60 \%$ of spore wall cleaved

$250 \mathrm{ppm}-40 \%$ of spore wall of cleavage

$100 \mathrm{ppm}-25 \%$ of spore wall cleavage

$50 \mathrm{ppm}$ - Mild cleavage of spore wall

$0 \mathrm{ppm}$ - Healthy spores

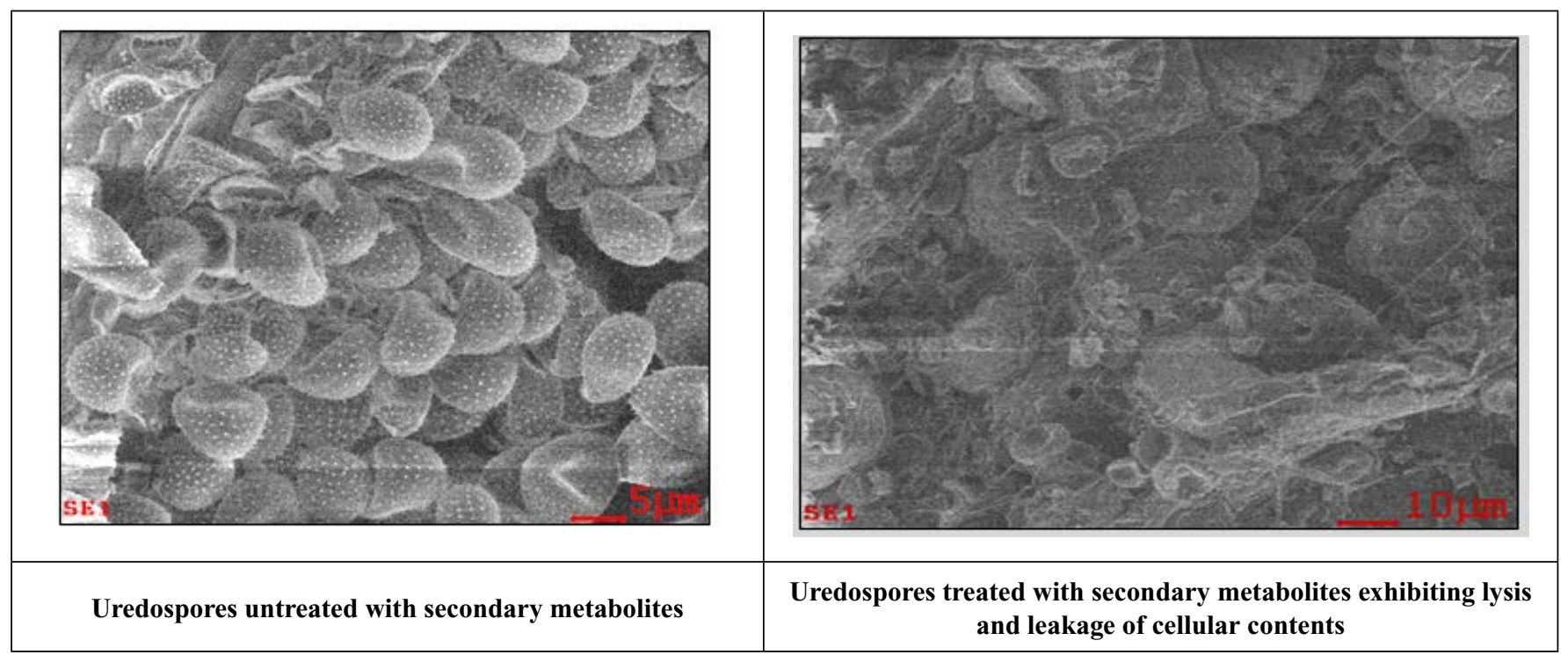

Plate 3: Scanning electron microscopy on the influence of secondary metabolites of Sphaerellopsis paraphysata on rust pustules 
Metabolites of the rust mycoparasite, Sphaerellopsis paraphysata for management of rust in pearl millet

Table 1. Morphological characters of Sphaerellopsis paraphysata

\begin{tabular}{|c|c|c|c|c|c|}
\hline S.No & Isolate & Cultural morphology & Mycelium & $\begin{array}{l}\text { Size of the conidia } \\
\qquad(\mu \mathrm{m})\end{array}$ & $\begin{array}{l}\text { Size of the pycnidia } \\
\qquad(\mu \mathrm{m})\end{array}$ \\
\hline 1. & TNAU-Sp1 & $\begin{array}{l}\text { Cottony, White, raised colonies, with } \\
\text { definite margin. }\end{array}$ & Hyaline septate & $11.1 \times 4.65$ & $141.21 \times 130.73$ \\
\hline 2. & TNAU-Sp2 & $\begin{array}{l}\text { Colonies were initially cottony, white but } \\
\text { later turned greyish on sporulation, raised } \\
\text { with definite margin. }\end{array}$ & Hyaline septate & $10.67 \times 5.12$ & $117.12 \times 106.78$ \\
\hline 3 & TNAU-Sp3 & White but centre turns grayish on sporulation & Hyaline, septate & $12.25 \times 4.68$ & $173.6 \times 163.56$ \\
\hline 4 & TNAU-Sp4 & $\begin{array}{l}\text { Whit, cottony, raised colonies with } \\
\text { definite margin }\end{array}$ & Hyaline, septate & $12.12 \times 5.25$ & $165.8 \times 153.46$ \\
\hline 5 & TNAU-Sp5 & $\begin{array}{l}\text { Greyish colonies with white centre, } \\
\text { margin was defenite }\end{array}$ & Hyaline, septate & $11.20 \times 2.16$ & $134.87 \times 123.04$ \\
\hline 6 & TNAU-Sp6 & $\begin{array}{l}\text { Greyish, raised colonies having } \\
\text { definite margin }\end{array}$ & Hyaline, septate & $12.84 \times 2.05$ & $132.1 \times 110.40 .6$ \\
\hline 7 & TNAU-Sp7 & $\begin{array}{l}\text { Whit, cottony, raised colonies with definite } \\
\text { margin,exude water droplets on sporulation. }\end{array}$ & Hyaline, septate & $12.51 \times 3.61$ & $141.09 \times 120.6$ \\
\hline 8 & TNAU-Sp8 & $\begin{array}{c}\text { Cottony, White, raised colonies, with } \\
\text { definite margin. }\end{array}$ & Hyaline, septate & $9.12 \times 4.61$ & $98.76 \times 87.54$ \\
\hline 9 & TNAU-Sp9 & $\begin{array}{c}\text { Cottony, White, raised colonies, with } \\
\text { definite margin }\end{array}$ & Hyaline, septate & $10.21 \times 4.32$ & $191.1 \times 187.24$ \\
\hline 10 & TNAU-Sp10 & $\begin{array}{c}\text { Cottony, White, raised colonies, with } \\
\text { definite margin. }\end{array}$ & Hyaline, septate & $12.42 \times 4.02$ & $191.1 \times 187.24$ \\
\hline 11 & TNAU-Sp11 & $\begin{array}{l}\text { Initially white and turns grayish on } \\
\text { sporulation, definite margin }\end{array}$ & Hyaline, septate & $11.68 \times 4.18$ & $134.1 \times 115.56$ \\
\hline 12 & TNAU-Sp12 & $\begin{array}{l}\text { Colonies were initially cottony, white but } \\
\text { later turned greyish on sporulation, raised } \\
\text { with definite margin }\end{array}$ & Hyaline, septate & $11.39 \times 4.32$ & $126.7 \times 104.56$ \\
\hline
\end{tabular}

Table 2. Secondary metabolites production in the crude extract of Sphaerellopsis paraphysata revealed through GC-MS

\begin{tabular}{|c|c|c|c|c|c|c|}
\hline Compound & $\begin{array}{l}\text { Retention } \\
\text { time }\end{array}$ & $\begin{array}{l}\text { Peak Area } \\
\text { Percentage }\end{array}$ & $\begin{array}{l}\text { Molecular } \\
\text { weight }\end{array}$ & $\begin{array}{l}\text { Molecular } \\
\text { formula }\end{array}$ & Properties & References \\
\hline Silane, triethyl (2-phenylethoxy)- & 3.314 & 0.247 & 236.43 & $\mathrm{C}_{14} \mathrm{H}_{24} \mathrm{OSi}$ & Anti fungal & Wang et al. (2012) \\
\hline Phenol & 3.459 & 28.748 & 94.113 & $\mathrm{C}_{6} \mathrm{H}_{5} \mathrm{OH}$ & $\begin{array}{c}\text { Anti } \\
\text { microbial, } \\
\text { Anti fungal. }\end{array}$ & $\begin{array}{l}\text { L.Jurd et al. (1971) } \\
\text { Ansari et al. (2013) }\end{array}$ \\
\hline Decane & 3.729 & 1.314 & 142.286 & $\mathrm{C}_{10} \mathrm{H}_{22}$ & $\begin{array}{c}\text { Anti } \\
\text { bacterial }\end{array}$ & Hameed et al. (2015) \\
\hline $\begin{array}{l}\text { 3-Butoxy-1,1,1,5,5,5-hexame- } \\
\text { thyl-3-(trimethylsiloxy) trisiloxane }\end{array}$ & 3.859 & 0.237 & 368.767 & $\mathrm{C}_{13} \mathrm{H}_{36}$ & Anti oxidant & Sujatha et al. (2017) \\
\hline $\begin{array}{l}\text { Butanoic acid, 3-methyl-, } \\
\text { 3-methylbutyl ester }\end{array}$ & 5.294 & 0.257 & 172.26 & $\mathrm{C}_{16} \mathrm{H}_{2} \mathrm{OO}_{2}$ & $\begin{array}{c}\text { Anti } \\
\text { bacterial }\end{array}$ & Brahmi et al. (2014) \\
\hline $\begin{array}{l}\text { Pyridine, 3-(1-methyl- } \\
\text { 2-pyrrolidinyl)-, (S)- }\end{array}$ & 8.771 & 0.750 & 162.231 & $\mathrm{C}_{10} \mathrm{H}_{14} \mathrm{~N}_{2}$ & $\begin{array}{l}\text { Anti fungal } \\
\text { and Anti } \\
\text { bacterial }\end{array}$ & Pavia et al. (2000) \\
\hline $\begin{array}{c}\text { 10,12-Tricosadiynoic acid, } \\
\text { TMS derivative }\end{array}$ & 9.781 & 0.433 & 418.727 & $\mathrm{C}_{2} \mathrm{H}$ & $\begin{array}{c}\text { Anti } \\
\text { microbial }\end{array}$ & $\begin{array}{l}\text { Divya Gupta et al. } \\
\text { (2016) }\end{array}$ \\
\hline $\begin{array}{c}\text { Cyclopropanedodecanoic acid, } \\
\text { 2-octyl-, methyl ester }\end{array}$ & 15.678 & 0.221 & 394.674 & $\mathrm{C}_{26} \mathrm{H}_{50} \mathrm{O}_{2}$ & $\begin{array}{c}\text { Anti } \\
\text { microbial }\end{array}$ & $\begin{array}{c}\text { Rajani Srivastava et al. } \\
\text { (2014) }\end{array}$ \\
\hline
\end{tabular}




\begin{tabular}{|c|c|c|c|c|c|c|}
\hline N,N-Dimethyldodecanamide & 13.693 & 0.366 & 227.38 & $\mathrm{C}_{14} \mathrm{H}_{29} \mathrm{NO}$ & $\begin{array}{c}\text { Anti oxidant, Anti } \\
\text { bacterial }\end{array}$ & Ololade et al. (2017) \\
\hline Tetra decanoic acid & 16.389 & 0.481 & 229.368 & $\mathrm{C}_{14} \mathrm{H}_{28} \mathrm{O}_{2}$ & $\begin{array}{c}\text { Anti microbial and } \\
\text { anti bacterial }\end{array}$ & Abubakar et al. (2016) \\
\hline
\end{tabular}

Table 3. Effect of different concentrations of crude metabolites on uredospores of Puccinia substriata in cavity slide and under glass house condition

\begin{tabular}{|c|c|c|c|c|c|c|}
\hline S.No & $\begin{array}{c}\text { Crude Extract Concentration } \\
(\mathrm{ppm})\end{array}$ & \multicolumn{3}{|c|}{$\begin{array}{c}\text { \% spore lysis (hours after } \\
\text { incubation) }\end{array}$} & $\begin{array}{c}\text { \% uredospore } \\
\text { germination }\end{array}$ & $\begin{array}{c}\text { \% reduction of rust } \\
\text { symptoms on foliage }\end{array}$ \\
\hline & & 24 & 48 & 72 & & \\
\hline 1. & 1000 & $32.7^{\mathrm{a}}$ & $63.34^{\mathrm{a}}$ & $92.67^{\mathrm{a}}$ & $13.6^{\mathrm{e}}$ & $92.6^{\mathrm{e}}$ \\
\hline 2. & 500 & $27.36^{\mathrm{b}}$ & $47.64^{\mathrm{b}}$ & $86.67^{\mathrm{b}}$ & $18.6^{\mathrm{d}}$ & $83.4^{\mathrm{c}}$ \\
\hline 3. & 250 & $24.64^{\mathrm{c}}$ & $41.61^{\mathrm{c}}$ & $84.67^{\mathrm{c}}$ & $21.6^{\mathrm{d}}$ & $78.9^{\mathrm{c}}$ \\
\hline 4. & 100 & $21.66^{\mathrm{d}}$ & $36.13^{\mathrm{d}}$ & $73.66^{\mathrm{d}}$ & $25.3^{\mathrm{c}}$ & $61.6^{\mathrm{b}}$ \\
\hline 5. & 50 & $18.61^{\mathrm{e}}$ & $31.43^{\mathrm{e}}$ & $62.66^{\mathrm{e}}$ & $40.0^{\mathrm{b}}$ & $56.3^{\mathrm{b}}$ \\
\hline 6. & Control (Sterile water) & $0.0^{\mathrm{f}}$ & $0.0^{\mathrm{f}}$ & $2.33^{\mathrm{f}}$ & $99.0^{\mathrm{a}}$ & $0.0^{\mathrm{a}}$ \\
\hline
\end{tabular}

*Values are means of three replications

Means in a column followed by same superscript letters are not significantly different according to DMRT at P $\leq 0.05$

fractions based formulation to control the rust diseases. The secondary metabolites based products are biologically originated and could serve as ideal components for ecofriendly management.

\section{REFERENCES}

Almeida AP, Dethoup T, Singburaudom N, Lima R, Vasconcelos, MH, Pinto M, Kijjoa A. 2010. The in vitro anticancer activity of the crude extract of the sponge-associated fungus Eurotium cristatum and its secondary metabolites. J Nat Pharm. 1:25-29. https:// doi.org/10.4103/2229-5119.73583.

Ansari MA, Khan HM, Khan AA, Pal R, Cameotra SS. 2013. Antibacterial potential of $\mathrm{Al}_{2} \mathrm{O}_{3}$ nanoparticles against multidrug resistance strains of Staphylococcus aureus isolated from skin exudates. J Nanopart Res. 15 (10):1970. https://doi.org/10.1007/s11051-013-1970-1.

Brahmi F, Abdenour A, Bruno B, Silvia P, Alessandra P, Danilo F, Drifa YG, Fahmi EM, Khodir M, Mohamed C. 2016. Chemical composition and in vitro antimicrobial, insecticidal and antioxidant activities of the essential oils of Mentha pulegium L. and Mentha rotundifolia (L.) Huds growing in Algeria. Ind Crops Prod. 88:96-105. https://doi.org/10.1016/j.indcrop.2016.03.002.
Chaudhary RF, Prajapati VP, Prashant Sandipan, Chaudhari KN. 2015. Efficacy of fungicides on uredospores germination of leaf rust of wheat. TIBS 8(11): 27352738 .

de Carvalho ADO, Soares DJ, do Carmo MGF, da Costa ACT, Pimentel C. 2006. Description of the life-cycle of the pearl millet rust fungus Puccinia substriata var. penicillariae with a proposal of reducing var. indica to a synonym. Mycopathologia 161(5):331-336. PMid: 16649083. https://doi.org/10.1007/s11046-006-0022-0.

Deora G, Guhil N. 2015. Phytochemical analysis and antifungal activity of moss bryum cellular against some phytopathogenic fungi. Int J Pharm Sci Res. 6(2):688691.

Driessen, SP, Brien O, Hardy GESJ. 2004. First record of the mycoparasite Sphaerellopsis filum on Puccinia boroniae in Australia. Australas Plant Pathol. 33(3):463-464. https://doi.org/10.1071/AP04048.

Gupta D, Dubey J, Kumar M. 2016. Phytochemical analysis and antimicrobial activity of some medicinal plants against selected common human pathogenic microorganisms. Asian Pac J Trop Dis. 6(1):15-20. https://doi.org/10.1016/S2222-1808(15)60978-1. 
Metabolites of the rust mycoparasite, Sphaerellopsis paraphysata for management of rust in pearl millet

Gordon T, Pfender W. 2012. Effects of the mycoparasite Sphaerellopsis filum on overwintering survival of stem rust in perennial ryegrass. Plant Dis. 96(10):1471-1481. PMid: 30727341.https://doi.org/10.1094/PDIS-10-110837-RE.

Jurd L, Corse J, King AD, Bayne H, Mihara K. 1971. Antimicrobial properties of 6, 7-dihydroxy-, 7, 8-dihydroxy-, 6-hydroxy-and 8-hydroxycoumarins. Phytochemistry 10(12):2971-2974. https://doi. org/10.1016/S0031-9422(00)97334-5.

Kishore GK, Pande, S. 2005. Integrated management of late leaf spot and rust diseases of groundnut (Arachis hypogaea L.) with Prosopis juliflora leaf extract and chlorothalonil. Int $J$ Pest Manage. 51(4):325-332. https://doi.org/10.1080/09670870500404567.

Kranz J, Brandenburger W. 1981. An amended host list of the rust parasite Eudarluca caricis/Eine ergänzte Wirtsliste des Rostparasiten Eudarluca caricis. Zeitschrift für Pflanzenkrankheiten und Pflanzenschutz. J Plant Dis Prot. 88(11):682-702.

Leyronas C, Duffaud M, Nocot P. 2012. Compared efficiency of the isolation methods for Botrytis cinerea. Mycology 3(4): 221-225.

Muhialdin BJ, Hassan Z, Bakar FA, Saari N. 2016. Identification of antifungal peptides produced by Lactobacillus plantarum IS10 grown in the MRS broth. Food Control 59:27-30. https://doi.org/10.1016/j. foodcont.2015.05.022.

Ololade Z, Fakankun O, Alao F, Udi O. 2017. Ocimum basilicum var. purpureum Floral Essential Oil: Phytochemicals, phenolic content, antioxidant, free radical scavenging, antimicrobial potentials. Life Sci. 14(7):1-8.

Plachecka A. 2005. Microscopical observations of Sphaerellopsis filum, a parasite of Puccinia recondita. Acta Agrobot. 58(1):67-71. https://doi.org/10.5586/ aa.2005.010.
Parthasarathy S. 2018. Development and standardization of liquid based bioformulation of Ampelomyces quisqualis Ces. for the management of pea powdery mildew pathogen Erysiphe pisi. Ph. D Thesis, Department of Plant Pathology, Tamil Nadu Agricultural University, Coimbatore, India.

Ravinder Reddy M. 1982. Evaluation of fungicides against major diseases of chilli. M.Sc. (Ag.) Thesis. Department of Plant Pathology, Tamil Nadu Agricultural University, Coimbatore, India.

Srivastava R. 2014. A review on phytochemical, pharmacological and pharmacognostical profile of Wrightia tinctoria: Adulterant of kurchi. Pharmacognosy Rev. 8(15):36-41. PMid: 24600194 PMCid: PMC3931199. https://doi.org/10.4103/09737847.125528 .

Venkatesan A, Kathirvel A, Prakash S, Sujatha V. 2017. Antioxidant, antibacterial activities and identification of bioactive compounds from Terminalia chebula bark extracts. Free Radic Antioxidants 7(1):43-49. https:// doi.org/10.5530/fra.2017.1.7.

Vincent JM. 1947. Distoration of fungal hyphae in the presence of certain inhibitors. Nature 150:850. PMid: 20343980. https://doi.org/10.1038/159850b0.

Wilson J, Hanna W, Gascho G. 1996. Pearl millet grain yield loss from rust infection. J Prod Agric. 9(4):543-545. https://doi.org/10.2134/jpa1996.0543.

Yuan Z, Pei M, Hunter T, Royle D. 1998. Eudarluca caricis, the teleomorph of the mycoparasite Sphaerellopsis filum, on blackberry rust Phragmidium violaceum. Mycol Res. 102(7):866-868. https://doi.org/10.1017/ S0953756297005832.

Zapf S, Hossfeld M, Anke H, Velten R, Steglich W. 1995. Darlucins A and B, new isocyanide antibiotics from Sphaerellopsis filum (Darluca filum). J Antibot. 48(1):36-41. PMid: 7868387. https://doi.org/10.7164/ antibiotics.48. 